\title{
Glycogen-Rich, Clear Cell Breast
}

\section{Carcinoma}

National Cancer Institute

\section{Source}

National Cancer Institute. Glycogen-Rich, Clear Cell Breast Carcinoma. NCI Thesaurus. Code C40368.

An uncommon, usually aggressive adenocarcinoma of the breast characterized by the presence of clear cells that contain glycogen. 